\title{
A proposal of a research model on internalization of quality standards using PLS
}

Research-in-Progress

\author{
Jorge Pereira-Moliner \\ University of Alicante, Spain \\ jorge.pereira@ua.es \\ José F. Molina-Azorín \\ University of Alicante, Spain \\ jf.molina@ua.es
}

\author{
Juan José Tarí \\ University of Alicante \\ jj.tari@ua.es \\ María D. López-Gamero \\ University of Alicante, Spain \\ md.lopez@ua.es
}

\begin{abstract}
This paper proposes a structural model to analyze the relationships between drivers of internalization of quality standards, internalization of quality standards, and performance in the Spanish tourism industry. First, the paper proposes hypotheses based on previous studies about internalization of quality standards and then measures to test the research model using partial least squares (PLS) path modelling are presented.
\end{abstract}

Keywords: Quality Management Standards, Internalization, Performance, PLS. 


\section{Introduction}

Most studies on the implementation and certification of quality management standards have measured such implementation through a variable that distinguished those organizations which did have a quality certification from those which did not (Sharma, 2005; Zaramdini, 2007; Benner and Veloso, 2008), thus assuming a homogeneous implementation of the quality standard. More recent studies have gone beyond this notion and analysed a heterogeneous adoption of the quality standards (Naveh and Marcus, 2004; Briscoe et al., 2005; Prajogo et al., 2012), that is, they have considered that those firms implementing a quality standard (e.g. the ISO 9001 standard), may develop its requirements in different ways (Nair and Prajogo, 2009; Boiral, 2011).

A heterogeneous adoption of a quality standard implies, on the one hand, that a firm may show a greater commitment towards the quality philosophy, and therefore develop the standard's requirements to a greater extent. On the other hand, another firm might show a lower interest towards the standard and, as a result, implement its requirements in a more symbolic way. In this latter case, the firm might be interested in obtaining a certificate which allows it to show its customers that it has some quality system, without any concern for what lies behind the certificate, i.e. the requirements of the quality standard.

There is limited research on the effects of internalization on the various dimensions of performance, and on which drivers might influence such relationship. Therefore, the aim of this study is to analyse which drivers, other than reasons for the implementation of a quality standard, may impact both internalization and the relationship between internalization and performance. Similarly, although it seems clear that internalization has effects upon operational and business performance, we are going to examine the impact of internalization on other dimensions of results, such as customer results, people results, and society impact. The contribution of this research work is to examine jointly the relationships between drivers of internalization, internalization, and different performance dimensions (customer results, people results, society impact, and business performance) extending previous research on internalization to tourism industry.

Based on previous studies on internalization and these gaps, first, this research work reviews the literature establishing a relationship between drivers, internalization of quality standards and performance, and proposes hypotheses. Finally, the next section shows the methods of this research work using partial least squares (PLS) path modelling. This paper is a work-in-progress that proposes hypotheses and a research model to test.

\section{Literature review and research hypotheses}

Most studies on the effects of quality certification upon performance have analyzed the "certification" variable as a dichotomic one, studying whether having or lacking a quality certificate has positive effects upon performance. However, the studies on internalization have considered a heterogeneous implementation, measuring the implementation and certification of a quality system as a set of items. Based on these studies, the reasons for the implementation of a quality system and other drivers may have an influence upon internalization.

The studies on internalization show that there are some factors which may influence this relationship, amongst which those more clearly analysed are the reasons for certification (Boiral and Roy, 2007; Martínez-Costa et al., 2008; Prajogo, 2011). The studies on internalization have also analyzed other drivers which might be considered in the future in order to explain other factors which might facilitate internalization, and thus an impact upon 
benefits. These other drivers which might play a role in the relationship between internalization and performance are the following (Briscoe et al., 2005; Naveh and Marcus, 2005; Christmann and Taylor, 2006; Singh, 2008): quality culture, leadership, pressure by stakeholders, innovation environment, and system coordination with suppliers and customers. These studies have shown that these drivers (that we can classify as internal and external drivers) may have positive effects on internalization. Internalization can be measured using two constructs: "daily practices" and "continuous improvement" (e.g., Naveh and Marcus, 2005). Accordingly, the following hypotheses are proposed:

\section{H1.1. External drivers have positive effects on internalization (daily practices) \\ H1.2. External drivers have positive effects on internalization (continuous improvement) \\ H2.1. Internal drivers have positive effects on internalization (daily practices) \\ H2.2. Internal drivers have positive effects on internalization (continuous improvement)}

Studies show that the higher the internalization level, the greater the operational and marketing benefits (Briscole et al., 2005; Naveh and Marcus, 2005; Jang and Lin, 2008). This is the case because firms develop the quality standard requirements to a greater extent. However, the effects on business performance are not so conclusive. According to Naveh and Marcus (2005), there could be direct effects of operational performance on business performance, although other factors which might affect this relationship should also be considered. Similarly, Jang and Lin (2008) pointed out that operational performance has an impact on business performance. These ideas show how internalization creates improvements which may impact operational performance such as, for instance, cost reduction, innovation and quality improvement (Nair and Prajogo, 2009). As a consequence, this may create a more open organizational culture which may increase sales (Huarng et al., 1999) and, therefore, may help to improve business performance. In this way, one might think that quality standard has not direct effects on business performance, and that operational performance could be a mediating factor on the effects of internalization on business performance (Naveh and Marcus, 2005; Nair and Prajogo, 2009).

Thus, greater internalization leads to greater benefits, because the firm may improve its management system, for instance, by improving the following processes: (a) planning control (the management may define objectives and indicators more clearly and may carry out periodic reviews of the quality system), (b) training (the firm may offer more training to managers and employees, which clearly will lead to improve in their work), (c) customer satisfaction (the firm may use methods in order to obtain feedback from customers and use such information in order to improve its processes and its products/services), etc.

In addition, quality management literature shows that quality management may have positive effects on customer results, people results, and society impact. Based on this general idea about the effects of quality management on different performance dimensions and previous studies on internalization, it might be interesting to analyze the impact of internalization on other dimensions of results, such as customer results, people results, and society impact. Accordingly, the following hypotheses are proposed:

\section{H3. Daily practices has positive effects on continuous improvement}

H4.1. Internalization (daily practices) has positive effects on customer results

H4.2. Internalization (continuous improvement) has positive effects on customer results

H5.1. Internalization (daily practices) has positive effects on employee results

H5.2. Internalization (continuous improvement) has positive effects on employee results

H6.1. Internalization (daily practices) has positive effects on society impact

H6.2. Internalization (continuous improvement) has positive effects on society impact 
H7. Customer results have positive effects on business performance

H8. Employee results have positive effects on business performance

H9. Society impact has positive effects on business performance

\section{Method}

\subsection{Population, data collection and variables}

The population of this study includes all hotels, travel agencies, restaurants, and country houses (as private organizations), and all tourism information offices and beaches (as public organizations) in Spain with a quality certificate (909 organizations). It was decided to study the whole population by means of a structured questionnaire with closed questions, which was sent in three waves between October 2014 and January 2015 by e-mail and ordinary mail. For the distribution of the questionnaire, support was received from the Instituto para la Calidad Turística Española (ICTE: Spanish Tourism Quality Institute), who also distributed the questionnaire among its members by e-mail. The questionnaire was addressed to the quality manager of each tourism organization. Finally, 407 completed questionnaires were received, that is, $47.8 \%$ of response rate. Table 1 shows the distribution of the sample by subsectors.

Table 1: Distribution of the sample and population by tourism subsectors

\begin{tabular}{|c|c|c|c|}
\hline Subsector & Sample (Frequency \%) & Population (Frequency \%) & $\begin{array}{c}\text { Response rate by } \\
\text { subsector }\end{array}$ \\
\hline Hotels & $176(42.9 \%)$ & $415(45.7 \%)$ & $42.4 \%$ \\
\hline Travel agencies & $20(4.9 \%)$ & $37(4.1 \%)$ & $54.5 \%$ \\
\hline Restaurants & $56(13.8 \%)$ & $179(19.7 \%)$ & $31.3 \%$ \\
\hline Country houses & $35(8.8 \%)$ & $94(10.3 \%)$ & $38.3 \%$ \\
\hline Beaches & $48(11.8 \%)$ & $88(9.7 \%)$ & $54.5 \%$ \\
\hline Tourism information offices & $71(17.1 \%)$ & $96(10.6 \%)$ & $74.0 \%$ \\
\hline TOTAL & 407 & 909 & $47.8 \%$ \\
\hline Square-Chi & $26.642 * * *$ & & \\
\hline
\end{tabular}

In order to check non-response bias (see Table 1), the variable subsector was used. This variable was applied because it is available for the sample and for the population. Table 1 shows that the frequencies of the sample and the population are related. Non-response bias was also checked following the method proposed by Armstrong and Overton (1977), comparing early respondents to the questionnaire with late respondents. The rationale is that late respondents are more similar to non-respondents that are early respondents. The data set was divided into three groups according to the number of days from initial mailing until receipt of the returned questionnaire. Comparing the first (early respondents) and the third (late respondents) groups of firms, it was confirmed that there were no significant differences in the mean responses for all the variables measured in the questionnaire. Therefore, it is presumed that the sample is not affected by any non-response bias problems, and then this group of organizations that participated in our study can be considered as representative of the population.

Furthermore, as the questionnaire was answered by only one respondent, we checked the presence of common method variance by applying Harman's single factor test (Podsakoff and Organ, 1986). After applying an exploratory factor analysis with Varimax rotation to all the variables measured, they were classified into 16 factors and the first one only explains around $32 \%$ of the total variance. Therefore, the observed relationships among constructs are not largely accounted for by the systematic variance associated with the measurement technique.

The variables in this study were measured employing a 7 point Likert scale (Table 2). 
Table 2: Measures

\begin{tabular}{|c|c|}
\hline External drivers & $\begin{array}{ll} & \text { Give confidence to customers } \\
\text { - } & \text { Improve public image } \\
\text { - } & \text { Protection and care of the environment } \\
\text { - } & \text { Management commitment }\end{array}$ \\
\hline Internal drivers & $\begin{array}{l}\text { - Quality culture existing continuous improvement in the organization } \\
\text { - Written documentation of the work methods in the organization } \\
\text { - } \quad \text { Neesire to organize and formalize in writing the working methods } \\
\text { - Innovativeness of the organization }\end{array}$ \\
\hline $\begin{array}{l}\text { Internalization - Daily } \\
\text { practices }\end{array}$ & $\begin{array}{l}\text { - The documents created for certification are used in daily practice } \\
\text { - The quality system becomes part of daily work routines } \\
\text { - } \quad \text { All employdits are prepared at the last moment } \\
\text { - The quality policy and the quality system procedures are updated in order to adapt them to daily } \\
\text { organizational practices }\end{array}$ \\
\hline $\begin{array}{l}\text { Internalization } \\
\text { Continuous } \\
\text { improvement }\end{array}$ & $\begin{array}{l}\text { - The development of the quality system makes it possible to introduce new improvement practices } \\
\text { - The quality standard has led the organization to discover improvement opportunities } \\
\text { Investing in time and resources in the quality standard is a starting point towards the } \\
\text { implementation of other more advanced practices } \\
\text { Investing in time and resources in the quality standard helps to reflect on the way work is done in } \\
\text { the firm and improve our work } \\
\text { Investing in time and resources in the quality standard is seen as an opportunity to innovate in our } \\
\text { organization }\end{array}$ \\
\hline Customer results & $\begin{array}{l}\text { - Increased customer satisfaction } \\
\text { - } \quad \text { Increased quality of service } \\
\text { - } \quad \text { Increased customer loyalty } \\
\text { - } \quad \text { Reduced customer complaints }\end{array}$ \\
\hline Employee results & $\begin{array}{ll}\text { - } & \text { Increased employee satisfaction } \\
\text { - } & \text { Increased employee motivation } \\
\text { - } & \text { Impreased employee productivity } \\
\text { - } & \text { Reduced absenteeism of employees } \\
\text { - } & \text { Reduction of employee complaints }\end{array}$ \\
\hline Society impacts & $\begin{array}{l}\text { - Increased environmental protection (reduction of resource consumption, pollution reduction) } \\
\text { - Improving the ethical behavior of the organization } \\
\text { - Increased levels of prevention of risks to health and safety (risk reduction accidents, etc.) }\end{array}$ \\
\hline Business performance & $\begin{array}{ll}\text { - } & \text { Increased market share } \\
\text { - } & \text { Increased sales } \\
\text { - } & \text { Increased profitability } \\
\end{array}$ \\
\hline
\end{tabular}

\subsection{Statistical analysis using PLS and research model}

The next step in this study applies PLS path modelling by means of the SmartPLS 2.0 software. PLS approach allows for the joint use of formative and reflective constructs in the same model. The two internalization constructs are considered as formative and the rest of constructs are reflective. In this way, for the reflective elements of the model, construct reliability, convergent validity and discriminant validity are going to be analyzed. For the formative constructs, different techniques are required from those used for the analysis of the validity of reflective constructs. These include checking for potential multicollinearity between its items and the weights from each item in order to explain its construct.

We are going to calculate the explained variance for each construct $\left(\mathrm{R}^{2}\right)$ and the regression or path coefficients $(\beta)$ between the constructs to evaluate the structural model and, therefore, to test the proposed hypotheses (Figure 1). After carrying out a bootstrap test with 5000 subsamples, the $\mathrm{t}$ statistic values are obtained for each $\beta$, which makes it possible to determine its significance.

In addition, we are going to test the model showed in Figure 1 grouping our sample into private and public tourism organizations employing multigroup procedures. This multigroup analysis could offer different results of the general model. 


\section{Figure 1. Research model}

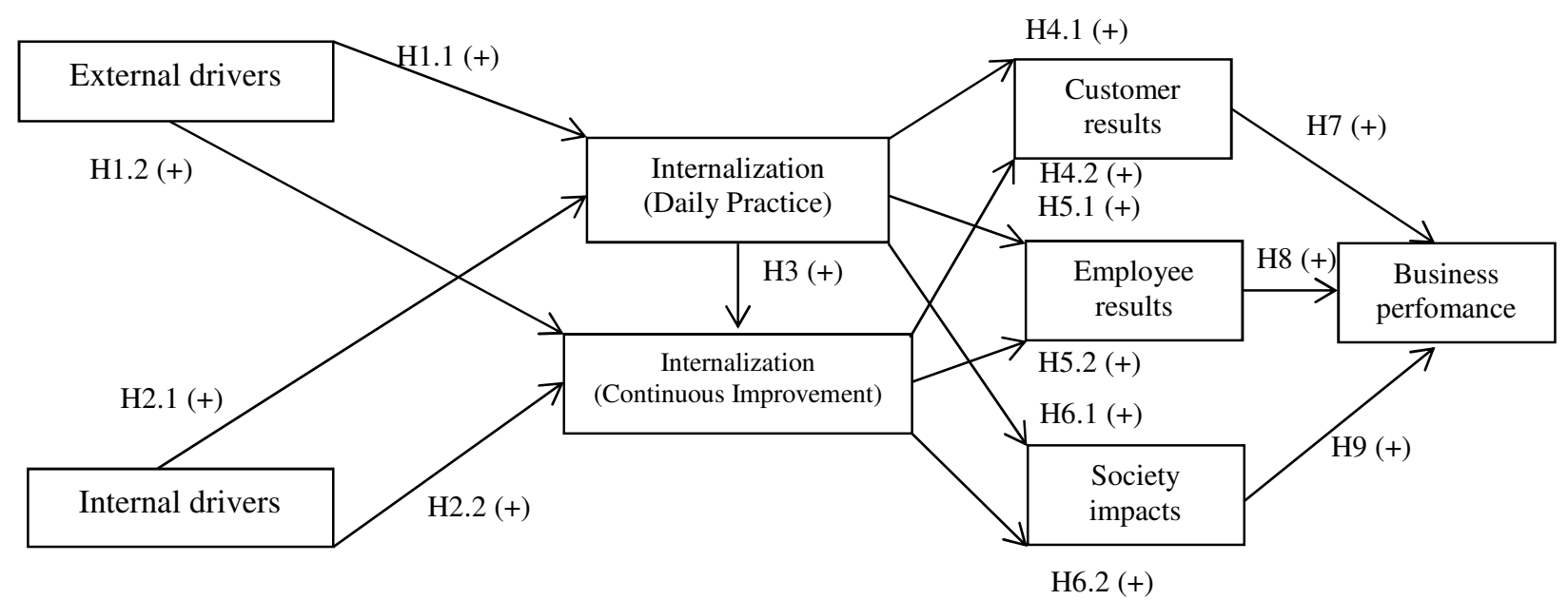

\section{Acknowledgments}

This work has been carried out as part of the research project ECO2012-36316 funded by the Spanish Government. The authors thank and acknowledge the support received.

\section{References}

Armstrong, J.S., \& Overton, T.S. (1977). Estimating non-response bias in mail surveys. Journal of Marketing Research, 14, 396-402.

Benner, M.J., \& Veloso, F.M. (2008). ISO 9000 practices and financial performance: a technology coherence perspective. Journal of Operations Management, 26, 611-629.

Boiral, O. (2011). Managing with ISO Systems: Lessons from Practice. Long Range Planning, 14, 197-220.

Boiral, O., \& Roy, M.J. (2007). ISO 9000: integration rationales and organizational impacts. International Journal of Operations \& Production Management, 27, 226-247.

Briscoe, J.A., Fawcett, S.E., \& Todd, R.H. (2005). The implementation and impact of ISO 9000 among small manufacturing enterprises. Journal of Small Business Management, 43, 309-330.

Christmann, P., \& Taylor, G. (2006). Firm self-regulation through international certificable standards: determinants of symbolic versus substantive implementation. Journal of International Business Studies, 37, 863-878.

Huarng, F., Horng, C., \& Chen, C. (1999). A study of ISO 9000 process, motivation and performance. Total Quality Management, 10, 1009-1025.

Jang, W-Y., \& Lin, C-I. (2008). An integrated framework for ISO 9000 motivation, depth of ISO implementation and firm performance. The case of Taiwan. Journal of Manufacturing Technology Management, 19, 194-216.

Martínez-Costa, M., Martínez-Lorente, A., \& Choi, T.Y. (2008). Simultaneous consideration of TQM and ISO 9000 on performance and motivation: an empirical study of Spanish companies. International Journal of Production Economics, 113, 23-39.

Nair, A., \& Prajogo, D. (2009). Internalisation of ISO 9000 standards: the antecedent role of functionalist and institutionalist drivers and performance implications. International Journal of Production Research, 47, 4545-4568. 
Naveh, E., \& Marcus, A. (2005). Achieving competitive advantage through implementing a replicable management standard: installing and using ISO 9000. Journal of Operations Management, 24, 1-26.

Naveh, E., \& Marcus, A.A. (2004). When does the ISO 9000 quality assurance standard lead to performance improvement? Assimilation and going beyond. IEEE Transactions of Engineering Management, 51, 352-363.

Podsakoff, P.M., \& Organ D.W. (1986). Self-reports in organizational research: problems and prospects. Journal of Management, 12(4), 531-544.

Prajogo, D., Huo, B., \& Han, Z. (2012). The effects of different aspects of ISO 9000 implementation on key supply chain management practices and operational performance. Supply Chain Management: An International Journal, 17, 306-322.

Prajogo, D.I. (2011). The roles of firms' motives in affecting the outcomes of ISO 9000 adoption. International Journal of Operations \& Production Management, 31, 78-100.

Sharma, D.S. (2005). The association between ISO 9000 certification and financial performance. The International Journal of Accounting, 40, 151-172.

Singh, P.J. (2008). Empirical assessment of ISO 9000 related management practices and performance relationships. International Journal of Production Economics, 113, 4059.

Zaramdini, W. (2007). An empirical study of the motives and benefits of ISO 9000 certification: the UAE experience. International Journal of Quality \& Reliability Management, 24, 472-491. 